\title{
Mizo Values in Agricultural Sustenance: Lessons from Mizoram
}

\author{
Lalthansanga, $\mathrm{C}^{1}$ \\ Mizoram University \\ ${ }^{1}$ lalthansanga2384@gmail.com
}

Keywords: Agriculture, Jhum, Cultivation, Mizo, Values, Mizoram, Mongoloid.

\begin{abstract}
The twenty third State of the Indian Union located in the north-eastern corner having a geographical area of 21,087 square kilometers is Mizoram. It is a hilly area differing largely in terms of topography from mainland India and also strategically placed as it shares an international boundary of 722 kilometers with Myanmar and Bangladesh. The Mizo tribes are unanimously held to belong to the Mongoloid race, in huge contrast to the inhabitants of most part of India. It is generally accepted by all historians that the point of migration starts somewhere in the ChinaBurma geographical landscape and that the pattern followed down-south towards the present modern State of Mizoram. The paper aims to elucidate on the priceless human values imbibed and practiced in the different stages of agricultural endeavors that has enabled the survival of the Mizo society. The Mizo society resembles a 'Prismatic Society', propounded by FW Riggs, in huge similarity to other south east Asian countries. It is believed that the paper will provoke thoughts and further research towards traditional value governance in the context of south east Asian countries.
\end{abstract}

Introduction

\section{Human Values:}

The word 'Human Values' have a positive connotation. It is normally ascribed to the core human principles leading to noble thoughts and deeds. Values influence the mind and then generate behavior of selfless conduct. It helps in determining the right course of action among many possible alternatives, the right course not always being the most beneficial or economically rewarding but morally satisfying. Human values provide guidance in ascertaining the best way to live one's life. In other words, neutrality is the opposite of values. A neutral stand taken by government in the administration of human affairs is considered to be value-less, while it is expected to propagate its values through administrative decisions and actions for the welfare of the less-privilege and weaker sections in the society. On the other hand, certain values held by one section of society or group can be disturbing or detrimental for others which gives a negative connotation of human values. Human values are internal and intangible while their sources of 
influence are primarily external and tangible. The physical environment and social interaction significantly built values over time. Likewise, the Mizo values are largely shaped by the trying times underwent in the process of their struggle to find sustenance in primitive form of agriculture.

\section{Who are the Mizos:}

The Mizo tribes are unanimously held to belong to the Mongoloid group. There are several theories in relation to their origin and reason behind their migration. History recorded in oral as well as written form carries with them the question of objectivity and subjectivity; they both have their advantages and limitations. To this date, oral records form a substantial part of the history of the Mizo people with regard to their socio-economic, social administration, pattern of migration and livelihood for sustenance. However, like many other geographical regions or society, socio-economic, political, and administrative happenings in the Mizo society find its place in the shelf of modern history with the advent of the British along the periphery of the region during the earlier part of eighteenth century. It is generally accepted by all historians that the point of migration starts somewhere in the China-Burma geographical landscape and that the pattern followed down-south towards the present modern State of Mizoram. In the course of their migration, there are physical evidences proving their occupation of several lands in the fertile valleys of Myanmar. Nevertheless, the pattern of migration continued downward towards the present State of much less-fertile lands and unforgiving topography. The logical theory behind this pattern of migration, from fertile valleys to harsh undulating hills and terrain, is the theory of migration induced by the variables of violence in relation to agricultural sustenance; the stronger tribes confiscating fertile lands and the weaker tribes further being pushed downwards. By the time the present location of the modern State of Mizoram is reached by the tribes moving down southwards from the valleys of Myanmar, they were surrounded apparently from different sides by other well-established kingdoms. The kingdom of Tripura in the west, that of Assam and Manipur in the north, and Bengal in the south. According to conventional theory, they eventually started a permanent settlement in what is now known as the State of Mizoram. Formally annexed by the British in the late nineteenth century, it became the twenty third State of the Indian Union. A landlocked State in the north eastern corner of India, it is sparsely populated with less than 11 lakhs population according to the latest census of 2011.

\section{Agriculture in the form of Shifting Cultivation:}

Shifting Cultivation also known as 'Slash and Burn' is the major method of cultivation practiced by the Mizos, given the nature of topography inhabited. As rudiment and primitive it may sound, the modern generation can never afford a mockery of it as it is the only phenomenon based on which the Mizo tribe have survived enabling posterity to see the light of day. As the name indicates, the place of cultivation is shifted every year to a different location. Plots of lands in the forest are prepared for cultivation by clearing and felling trees and bamboos which are then left to dry and then burnt after several days. The ashes from burning serves as a source of potash for the soil. Seeds are sown at the onset of monsoon rains mainly during the months of 
April and May. After rigorous stages of maintaining the plot by weeding periodically, harvest season normally arrives during the months of November and early December. In the succeeding year, new plot of land is prepared while the previous plot is left to regenerate and thus lie fallow. The practice continues every year until they revert back to the earliest regenerated plots after few years following the cycle of shifting their cultivation. Shifting Cultivation is practiced in different parts of the world. While the major pattern of cultivation is the same in many countries, there is a uniqueness attached to each particular tribe in the way it is practiced. Agriculture in the form of Shifting Cultivation is one major foundation of the traditional Mizo society. Its administration and coordination, however inadequate it may sound, is imbibed within the societal fabrics itself. Every household and every village strive towards their goal of bumper harvest so as to attain self sufficiency. In the course of this endeavor, an element of coordination exists; build upon the foundation of a closely-knitted society conceiving traditional values which instilled a deep sense of bonding and camaraderie thereby facilitating the coordinating needs in their agricultural endeavors. Jhum cultivation was a major phenomenon defining their lifestyle, relationship, and daily activities. Behind the hardship and every day struggle in meeting the harsh demands of Jhum cultivation, lies the spirit of mutual support, empathy, and collective efforts bringing a life of fun, happiness, and joy.

Before the advent of British administration in the erstwhile Lushai Hills, the village chief and his coterie of officials represented a single structure performing different functions over their subjects. The biggest and most important function that the Chief and his officials performed was in the agricultural sector, as agriculture was the life-line where all else hinges upon, in the traditional Mizo society. In contrary to the rigid societal structure of caste and creed existing in other Indian societies, there was not much hierarchical barrier in the traditional Mizo society except for the existence of the village Chief and his Council of 'Elders' discharging administration over the general masses. In other words, there was the existence of only a short hierarchical chain which can be seen as a necessity or a glutinous adhesive binding the societal fabrics into becoming a closely knitted society. Agriculture was a major phenomenon around which all other variables of the society were based upon. Apart from the formal hierarchical structure consisting of the village Chief and his 'Elders', it is only within the domain of distribution of agricultural plots that an element of hierarchy was found. This can also be seen as a necessary strategy for the purpose of coordinating agricultural pursuits. In other sense, it is safe to say that the inherent hierarchical chain in the distribution of agricultural plots was a major form of agricultural coordination in the traditional Mizo society. The household of the village Chief occupied the hierarchical apex in the sphere of distribution of agricultural plots. It was the prerogative of the royal family to allocate themselves agricultural plots of their own choice in relation to the size, topography and other natural advantages like rivers and strategic location of the plots from the village. However, it was a general practice of the Chiefs not to engage themselves in 'Jhum' cultivation as there was a traditional provision in place for them to receive tribute from every household of their subjects, in the form of rice. This traditional provision called 'Fathang' in the Lushai dialect was practiced amongst the different tribes across different 
villages uniformly except for its quantity. It is a fact that administration was carried-on based on unwritten norms, traditional principles and values which were subjected to modifications by the ruling Chiefs and their official of 'Elders'. As such, the quantity of rice given as a tribute to the Chief may vary from one village to another depending upon the decision of their respective Chiefs. The British Superintendent, N.E. Parry in a bid to streamline his administrative process, passed an order to the Chiefs of different villages in 1927 that the quantity of rice given as 'Fathang' be made uniform to six baskets of rice from every household (Darchungnunga, 2015). The traditional handcrafted baskets were normally used for the purpose of measuring the quantity of rice. The second place in the order of hierarchy were occupied by siblings of the Chief from different household living in the same village, irrespective of whether or not they belong to the Chief's Council. With due privileges given to the royal family, the Council members of the Chief are the next in line who enjoy the benefit of choosing agricultural plots of their choice before all other remaining subjects. These members also called as 'Council Elders' or 'Zalenpui' were usually hand-picked by the Chief and they formed the major backbone of their society assisting the Chief in the administration of different sectors ranging from defense and agriculture to judicial and festivities. There often is a debate on the issue of whether these council members were free from paying the traditional rice tribute to the Chief of their village. Some historians write that they were exempted while some writes they were not. This could be true in either way as the Chief in one village functioned independently from another village, particularly between those of Chieftainship in the south and that of the north. However, there is a general consensus among all writers with regard to the hierarchical position of the Chief's council members in distribution of agricultural plots. After selection of agricultural fields by the Chief's council members as per their own suitability, there was a small section of prominent households called 'Zalen te', who were entitled to choose agricultural fields before the general public does. These are family chosen by the Chief to be such, and in return the Chief can demand of them their livestock of pigs and chicken for hosting a banquet, especially for the purpose of showing hospitality to his eminent guests. Agriculture was much labor intensive in the earlier times, with no mechanization of works. Manpower was the most significant factor to undertake farming in large scale, or say, to cultivate larger fields. Household having more adult members who can contribute significantly in the fields are naturally in a better position to harvest more than smaller households. These larger households, better suited for more harvest often seek the privilege of choosing agricultural plots of their choice and size by promising the Chief in terms of paying additional quantity of the traditional rice tribute. The Chief usually accede to their proposal and grant them the privilege depending on the amount of rice tribute that they promise to submit, i.e., the larger quantity of rice they are willing to submit, the better chances of choosing the fields before others. Such households were known by the name 'Ram-hual'. The general subjects are the last to choose agricultural plots of their choice. By the time their chances arrived, they have already made a decision of the plots they would like to have depending on the earlier selection at the higher level. The traditional practice is that a specific day was designated by the Chief and his council members for the general subjects to choose their plots. 
On the designated day, it becomes a task of each household to venture-out as per their convenience and select the plots themselves on the spot. The underlying rule is that the vacant plots shall be taken by the person reaching the place before others. For this purpose, they usually leave at the crack of dawn with the intention of selecting their pre-determined plots before others could reach the place (Darchungnunga, 2015).

As mentioned earlier, Shifting Cultivation is the biggest phenomenon defining the lifestyle, relationships, social norms and values of the traditional Mizo society. It is a natural force that place all households in the village on equal footing and same standard of living. It creates an element of commonality where all are concern in the same subject of survival through Shifting Cultivation throughout the different seasons of the year. The insecurity created by the vagaries of nature throughout the different stages of shifting cultivation is one major factor that foster the values of altruism and brotherhood by which the harsh reality in the journey of shifting cultivation is traversed as one closely-knit family. There are instances in the different stages of shifting cultivation in which the forces of nature are fought as one and where such values of altruism are exhibited.

\section{'Fehkawng Sial'}

The Jhum plots are usually few miles away from the periphery of the village, in the forest. A coordinated effort of paving the jungle road known as 'Fehkawng Sial' is initiated by the community. All households are required to contribute manpower for this purpose or else they will contribute in different forms as per the decision of the community. This jungle road will be used by all as it leads to the main area of the forest where the Jhum plots are located. They would leave for their respective plots towards the forest in groups and returned in groups in the evening; a time of harmless frivolity and fun shared on their way back to the village after a hard day's work and also a mode of safety from fearsome wild animals in the forest.

\section{'Lo Vah'}

The clearing or slashing of thick forest land so as to dry it and burn, also known as 'slash-andburn', in order to prepare it for Jhum plots was the biggest hurdle in the cycle of Jhum cultivation. It is usually meant for the able men and bachelors of the household to tackle such a grinding task deep in the forest. As a way of coordination, several men from several households who were about to have their respective Jhum plots within the same area would join together and construct a makeshift hut to be used as their base where they will eat and sleep together during the trying times of clearing their own plots of thick and infested forest. The makeshift huts were usually built at a strategic location where water is of easy access for the purpose of cooking, drinking, and bathing. The members of such makeshift huts need not necessarily be blood related families, but would consider themselves as family due to their common cause and struggle. Palatable meals of wild fowl and other animals hunted or caught in traps were shared by all. Every morning they would disperse towards their own plots and toil under rain and sun, clearing the forest with their bare tools of axe and blades. The late evening and night offers repose from their punishing routine - a time for songs and dialogues. 


\section{'Lo Hal'}

After the clearing of thick and infested forest lands known literally as 'Slashing' is over, the next stage is to bake the felled trees and shrubs under the sun for the purpose of clearing them by burning. Thus, came the other name of Shifting Cultivation, 'Slash and Burn'. After baking the forest land for several days, careful preparations are made for burning the dried fallen trees and shrubs so as to avoid unnecessary forest fire knowing fully well that the virgin forests serve to sustain their practice of Shifting Cultivation for successive years. Concern for the common good is exhibited by paving road for the fire so as to demarcate the area to be ravaged by the forest fire and that to be left unburned. This work is executed by members of the community on the basis of voluntary work contribution known as 'Hnatlang'.

\section{'Inlawm'}

Another form of coordination known as 'Inlawm' was prevalent, mainly during the weeding stages of Jhum cultivation. This practice of 'Inlawm' occurs when two or more people enter into a mutual agreement of helping each other in the fields. The help meted out by one will be repaid by the other by working for the same number of days in the former's field. This mutual contract is common among group of friends and neighbors. It also offers good chances for boys and girls to court each other in the fields without compromising their work.

\section{'Inkhaichhuah'}

Efforts were coordinated to make sure widows and household having serious infirmities were not left behind by helping them manually in the fields. It was customary especially for the people in the neighboring plots to provide free and voluntary labor for such family who are incapable of working their way out of the various stages in the cycle of Jhum cultivation. The different hurdles or stages involved in Jhum cultivation from distribution of plots, slash-and-burn, to the time of sowing, weeding and harvesting were tackled and faced together as one, with the intention of leaving no one behind, and no one having the intention of lagging behind to be a burden for others. A peculiar system of 'Inkhaichhuah' comes into operation when members who are slow and struggling behind in the course of clearing their plots are voluntarily assisted by their friends from the makeshift hut. If their situation is such that it is beyond the capability of their friends to bail them out, the entire community will be mobilized towards their rescue (Darchungnunga, 2015).

\section{Conclusion}

In their effort to achieve sustenance through agriculture, invaluable norms and values are cultivated over time. The commonality of problems and hurdles to be overcome by each 
household in their struggle for sustenance through-out the stages of shifting cultivation has created a spirit of oneness and mutual support for one another. The uncertainty and hardship posed by the rigorous nature of shifting cultivation is a major concern of all families, and is inarguably the biggest phenomenon that engulfed and shape their lives and sentiments. Agriculture in the form of shifting cultivation is seen as a major force to be reckon with: a battle demanding strong will-power as well as raw strength bind by the fabrics of altruistic values inculcated from the practical experiences faced on the field of their battle with different forces of nature in all seasons. Failure to harvest a sustainable amount of paddy is regarded as disgrace for one's family while failure of others is seen as shameful of their neighbors who are in close proximity to their agricultural plots or even the village as a whole, for being indifferent and not lending extra hands to ensure they survive through the test of times. In light of this sentiment, a diehard statement expressing their core values is conceived: "Dam leh mual khatah, thih leh ruam khatah", which can be literally translated as, "If we survive, we live on the same field, if we die, we die in the same valley".

Lessons: Methods and administration may change with the adoption of modern technologies and governance. Nevertheless, the flame of traditional values and norms burn bright in the hearts and minds of the people as they are embraced and passed down from one generation to the other. Policies and schemes formulated on the lines of cherished traditional values are accepted by the masses with more ease thereby facilitating its execution with efficacious result. This notion of blending modern agricultural policies and schemes with traditional social norms and values at a permissible limit seems to be absent in the present agricultural scenario of Mizoram. For instance, the scheme of distributing chemical fertilizer to the farmers which was undertaken by the departmental functionaries has been ironically handed to government approved suppliers. Government approved suppliers who are in close proximity to politicians have the sole concern of profit maximization rather than farmer's welfare. In other words, farmer's destiny, to a considerable extent, lie at the mercy of the suppliers who possess less care for their welfare. Fertilizers at the stockyard of suppliers are often sold on the other side of the border, in Myanmar, at exorbitant rates while farmers are devoid of the vital inputs. This is a classic example elucidating the neglect of traditional values in modern administration. A viable alternative on the part of the government would be to licensed a registered farmers' society and permit them to disburse fertilizers among their farmer members. This is where the values of altruism and mutual support will set-in among the farmers who shall cater to their needs as they distribute inputs with concern for one another. 'Public Value Governance' in the right sense and at appropriate level is the need of the hour. 


\section{REFERENCES}

Chambers, Captain O.A.( 2005.) Handbook of the Lushai Country, FIRMA KLM Private Limited, Kolkata,

Chatterjee, Suhas (1985.), Mizoram under the British Rule, Mittal Publications, Delhi

Darchungngunga, Rev. (2015.) Zofate Sulhnu, Self-published with financial assistance from Mizoram Publication Board, Aizawl,

Hrahsel, Lalchhuanawma, (2014.) Mizoram Statistics, Self Published, Aizawl,

Hrangthiauva (2011.), Mizo History, C. Chhuanvawra \& Sons, Aizawl,

Joshi, H.G (2005). Mizoram: Past and Present, Mittal Publications, New Delhi,

Khiangte, Laltluangliana (2008), Mizos of North East India, L.T.L. Publications, Aizawl,.

Lalniliana, C (2012). Tuantul, Department of Agriculture, Mizoram, Aizawl,.

Lalrinmawia (1995), Mizoram: History and Cultural Identity, Spectrum Publications, Guwahati,.

Lewin, Thomas Herbert Lt. Col (1912.). A Fly on the Wheel or How I Helped Govern India, Tribal Research Institute, Mizoram, Aizawl,

Lewin T.H (2004.). The Hill Tracts of Chittagong and the Dwellers Therein, Tribal Research Institute, Mizoram, Aizawl,

Malsawmdawngliana and Rohmingmawii,(2013.) (ed.), Mizo Narratives: Accounts from Mizoram, Scientific Book Centre, Guwahati,

Ralte, Lalhruaitluanga (2008.), Zoram Vartian, Fineprints, Aizawl, 
Ralte, Lalhruaitluanga (2013), Thangliana (Lt. Col. Thomas Herbert Lewin), Fineprints, Aizawl,.

Sangkima (2004), A Modern History of Mizoram, Spectrum Publications, Guwahati,

Thanmawia R.L (2011). Mizo Values, Din Din Heaven, Aizawl,.

Tribal Research Institute (1978.), The Lushais. Aizawl, Government of Mizoram, Aizawl,

Vanlalzuata, (ed.) (1990.), Champhai Centenary Souvenir, The Souvenir Department, Champhai,

Zofa, Lalchhanhima (1999.), Champhai Rahbi, T.J. Lalnuntluanga, Champhai, 